Шпинев Юрий Сергеевич

Кандидат юридических наук Старший научный сотрудник сектора предпринимательского и корпоративного права Института государства и права РАН

\title{
ПРОБЛЕМЫ РАЗВИТИЯ РЕГИОНАЛЬНОЙ СИСТЕМЫ КАПИТАЛЬНОГО РЕМОНТА МНОГОКВАРТИРНЫХ ДОМОВ
}

Аннотация: В статье рассматриваются проблемы развития региональной системы капитального ремонта многоквартирных домов. Автором рассмотрены нормативные акты по вопросу ремонта многоквартирных домов, изучено общее состояние жилищного фонда, а также выявлены основные проблемы, мешающие развитию системы капитального ремонта жилых зданий. В итоге автор делает вывод, что решение выявленных проблем будет способствовать развитию региональной системы капитального ремонта многоквартирных домов.

Ключевые слова: капитальный ремонт, многоквартирные дома, жилищное хозяйство.

Keyword: major repairs, apartment buildings, housing.

Создание уютных и надежных условий проживания, обеспечение безопасности жилищного и доступности фонда, удобного доступа к жилищно-коммунальным услугам, отвечающим современным стандартам качества, являются основными задачами развития сферы жилищного хозяйства. В конечном счете, положительное решение этих вопросов призвано значительно увеличить качество жизни граждан. Вместе с тем решение этих задач тормозится неудовлетворительным состоянием жилищного фонда.

Вопросы развития и ремонта жилищного фонда неоднократно были предметом рассмотрения российских ученых (Н. Н. Минаев, А. А. Селиверстов, Н. Р. Шадейко К. Э. Филюшина, Ю. А. Меркульева [1], В. И. Мищенко, А. И. Гудков, Д. И. Долотова [2], Г. А. Хмелева, Д. Ю. Трифонова [3], К. К. Шрейбер, Е. А. Король [4]).

Вместе с тем с учетом постоянно меняющейся экономической, политической и социальной ситуации в мире в целом и России в частности, часть исследований в 
определенной степени утратили актуальность, в то время как важность и неполное теоретическое освещение требуют продолжение рассмотрения указанной проблемы.

По данным Росстата (раздел Жилищные условия) площадь аварийного жилья в России начиная с 2000 года выросла больше, чем 2, 5 раза и на 2018 год составляла 25,5 млн. м2 [5].

Ранее преодолеть увеличение ветхого и аварийного жилья был призван Федеральный закон от 21.07.2007 № 185 «О Фонде содействия реформированию»[6]. Указанный фонд несколько сгладил ситуацию, но полностью решить проблему ветхого и аварийного жилья конечно не мог. Так, на 01.01.2014 осуществлен капитальный ремонт почти 150000 многоквартирных домов, насчитывающих более 18 млн. человек. Несмотря на положительные сдвиги, темпы ремонта недостаточны, поскольку при их сохранении до 2025 более 300 млн. м2 жилья будут непригодными для проживания [7].

Таким образом, ввиду систематического увеличения объемов отложенного капитального ремонта жилищного фонда, создается реальная угроза появления нештатных и аварийных ситуаций на объектах ветхого жилого фонда, что создает реальную опасность для проживающих там людей.

Обветшание жилого фонда представляет собой непрерывный процесс, противостоять которому можно исключительно используя системный подход и постоянный контроль за постоянно ухудшающимся жилищным фондом.

В соответствии с жилищным законодательством, начиная с 2005 года бремя капитального ремонта было возложено на собственников жилого помещения, в то время как сам механизм разработан не был.

Основная часть капитального ремонта осуществлялась с помощью специальных программ, некоторые из которых предусматривали финансовое участие собственников жилья, которое было либо добровольным, либо минимальным. С учетом всех этих нюансов скорость капитального ремонта была крайне небольшая.

Для решения сложившейся негативной ситуации в сфере капитального ремонта многоквартирных домов в 2012 году в Жилищный кодекс Российской Федерации [8] был введен раздел IX Организация проведения капитального ремонта общего имущества в многоквартирных домах. Таким образом, в действующем законодательстве был применен новый способ финансирования, заключающийся в том, что основная часть ответственности за состояние и ремонт жилищного фонда была возложена на региональные власти. Законодатель подробно установил полномочия всех органов власти, 
участвующих в капитальном ремонте, а также механизм участия граждан по вопросам капитального ремонта многоквартирного жилого дома. Так, был определен механизм регулярного перечисления собственниками жилых помещений денежных средств для накопления и дальнейшего проведения капитального ремонта.

Существенными полномочиями наделены субъекты Российской Федерации, имеющие возможность самостоятельно определять минимальный размер взноса, сроки и порядок мониторинга многоквартирных домов, выбор регионального оператора и другие вопросы.

Одним из нововведений было применение двух вариантов аккумулирования денежных средств для дальнейшего капитального ремонта. Первый способ предусматривает использование для этого специального счета одного многоквартирного дома, второй - перечисление денежных средств на счета регионального оператора.

Несомненно, указанные новшества были своевременными. Вместе с тем новый механизм финансирования капитального ремонта мест общего пользования в многоквартирных домах сталкивается с определенными трудностями, которые мешают проведению полномасштабной реформы ЖКХ в части капитального ремонта многоквартирных домов.

В первую очередь к таким проблемам можно отнести недостаточно проработанный механизм мониторинга жилищного фонда как на федеральном уровне, так и на уровне конкретных регионов. Между тем постоянное отслеживание состояния жилого фонда совместно с систематическим анализом ситуации представляется обязательным условием для построения надежного механизма сохранности жилищного фонда.

В соответствии с нормативными актами в региональную программу подлежат включению все жилые многоквартирные дома с обязательным установлением срока капремонта.

Однако по настоящее время во многих регионах нет полных данных о техническом состоянии зданий и уже проведенных в них ремонтах. Не редки случаи, когда технической документации по конкретному дому просто нет. Часто данные, предоставляемые уполномоченными органами и лицами носят субъективный характер, что существенно снижает возможность применить системный подход к капитальному ремонту многоквартирных домов.

Сложившаяся ситуация приводит к созданию и утверждению региональных программ, которые имеют недостоверную информацию, в то время как на такой информации формируется очередность капитального ремонта. 
Данная ситуация отрицательно сказывается на составление грамотного финансового планирования. Помимо это с помощью таких недостоверных данных невозможно точно спрогнозировать социально-экономическую ситуацию в том или ином регионе в более-менее долгосрочной перспективе.

Для решения указанной проблемы важным и целесообразным представляется создание специальной методики постоянного отслеживания состояния жилого фонда. Такая методика должна включать себя конкретные технические и социально значимые показатели для принятия решения по включению многоквартирных домов в программу капитального ремонта, сроки проведения проверок, конкретных должностных лиц, ответственных за измерение и внесение определенных показателей.

Следующей проблемой на пути проведения полноценной жилищно-коммунальной реформы представляется полное отсутствие системы увеличения энергоэффективности многоквартирных домов во время капитального ремонта.

Несмотря на то, что действующие нормативные акты предписывают в обязательном порядке ремонтировать все дома, на практике такой ремонт часто выливается в осуществление каких-то определенных, наименее дорогостоящих работ, которые не способны существенно улучшить многоквартирные дома, и тем более, увеличить их энергоэффектиность. Никто не сомневается, что капитальный ремонт аварийных и ветхих жилых зданий представляет собой важную задачу. Вместе с тем задача повышения энергоэффективности также представляет собой одну из приоритетных направлений государственной политики.

Вопросам улучшения механизмов системы энергоэффективности жилого фонда посвящены работы как российских ученых, О. С. Голубовой [9], Т. Р. Терешкиной, А. С. Семенова [10], В. В. Бузырева, И. В. Дубровской [11], так и зарубежных [12-17].

Жилищный фонд нашей страны занимает второе место среди всех конечных потребителей России, вследствие чего имеет большие возможности для энергосбережения. В случае продуманного капитального ремонта, основанного на модернизации, энергоэффективность может быть увеличена в два раза [18]. Увеличение энергоэффективности жилищного фонда в долгосрочной перспективе будет способствовать уменышению затрат на дальнейший капитальный ремонт, а также снижению коммунальных платежей. Таким образом, эти два процесса, капитальный ремонт и повышение энергоэффективности, должны быть взаимосвязаны, что, в конечном счете, даст наилучшие результаты при осуществлении региональных программ капитального ремонта многоквартирных домов. Следует также отметить, что проведение 
работ по энергоэффективности дома в период его капитального ремонта намного выгоднее, чем несколько отдельных точечных ремонтов [19].

Между тем решение этой задачи тесно связано с проблемой неэффективной финансовой политики при проведении капитального ремонта одновременно с повышением его эергоэффективности. Действительно, действующим законодательством жестко регламентируются виды работ и услуг, выполняемых в процессе капитального ремонта общего имущества в многоквартирном доме, которые финансируются из средств капитального ремонта, сформированного из расчета минимального взноса. В эти работы в частности входят ремонт внутридомовых инженерных систем электро-, тепло-, газо-, водоснабжения и водоотведения, крыши, фасада, фундамента и подвальных помещений, а также ремонт или замена лифтового оборудования.

Субъекты Российской Федерации наделены полномочиями расширить этот список. Согласно Жилищному кодексу субъект своим нормативным актом должен установить максимальную стоимость работ по осуществлению капитального ремонта общего имущества в многоквартирном доме, которые могут быть оплачены за счет средств фонда, созданного исходя из минимального размера взноса на капитальный ремонт.

При увеличении этой стоимости ремонт должен быть оплачет за счет средств собственников дома, уплачиваемых свыше минимального размера. Аналогично обстоит ситуация, когда производятся работы или оказываются услуги, не включенные в перечень. В случае же проведения совместно с капитальным ремонтом работ по увеличению энергоэффективности, их стоимость будет заведомо превышать закрепленные нормативы максимальной стоимости работ по капитальному ремонту общего имущества в многоквартирном доме. В итоге, при осуществлении энергоэффективной модернизации совместно с проведением капитального ремонта возникает вопрос поиска дополнительных источников финансирования. К таким источникам могут быть отнесены внебюджетные источники, кредиты, а также частные инвесторы. При этом необходимо отметить, что потенциальные инвесторы не очень стремятся участвовать в таких проектах. Эти проекты являются более рискованными, ресурсозатратными, долгосрочными, в то время как отдача от таких инвестиций будет ниже, чем с аналогичного размера инвестиций в другие сферы экономики, особенно в финансовый сектор и добывающую промышленность. В тоже время и собственники жилых помещений не могут получить необходимый для капитального ремонта общего имущества в многоквартирном доме кредит ввиду неразвитости кредитной системы для этих целей, включающей в себя в первую очередь 
вопросы обеспечения кредита, определения заемщика и закрытого списка банков, которые могут создавать специальные счета.

Одним из способов решения данной проблемы может стать государственноечастное партнерство. Удачным решением представляется софинансирование работ по энергосбережению многоквартирных домов в период их капитального ремонта государством с помощью заключения энергосервисных договоров.

Еще одной важной проблемой представляется отсутствия надлежащих гарантий проведения своевременного и качественного капитального ремонта ввиду недостаточной финансовой устойчивости регионального фонда, как основного элемента регионального механизма капитального ремонта общего имущества в многоквартирных домах. Действующее законодательство не содержит необходимых механизмов гарантии сохранности, собранных собственниками жилых домов денежных средств. В качестве рисков в данном случае можно рассматривать незапланированную инфляцию, способную существенно снизить размеры капитального ремонта, а также требования со стороны кредиторов.

Кроме этого, нет четкого понимания финансовой устойчивости региональной программы капитального ремонта в случае, если в регионе одна из моделей накопления денежных средств существенно превалирует над другой. Вследствие неэффективного мониторинга, о чем было сказано выше, есть вероятность неточного прогнозирования объема финансов, которые могут быть потрачены на капитальный ремонт.

Перечисленные выше проблемы создают риск возникновения ситуации, когда накопленных на счете регионального оператора денежных средств в полном объеме не хватит на осуществление качественного капитального общего имущества всех многоквартирных домов.

Не способствует комплексному проведению капитального ремонта и отсутствие надлежащего взаимодействия между всеми участниками процесса, в том числе на различных уровнях власти. Для осуществления разных вариантов механизмов капитального ремонта в субъектах с учетом местной специфики действующее законодательство делегировало им право самостоятельно устанавливать порядок деятельности и организации региональных систем капитального ремонта. В развитие норм Жилищного кодекса законы регионов должны установить полномочия органов местного самоуправления в области организации и осуществления капитального ремонта общего имущества в многоквартирных домах. Вместе с тем все муниципальные образования имеют свою специфику и особенности, в том числе по уровню развития инфраструктуры, 
финансовым возможностям, климатическим условиям, составу и численности населения. Представляется целесообразным привлекать муниципалитеты к активному участию в разработке региональных программ капитального ремонта в многоквартирных домах с целью вносить в эти программы необходимые корректировки с учетом местных особенностей для предотвращения в будущем связанными с такими особенностями возможных проблем. Для решения этой задачи необходимо обеспечить региональные системы капитального ремонта на местном уровне необходимым методическим материалом. Местные особенности муниципалитетов необходимо обязательно учитывать также в процессе определения минимального размера взноса за капитальный ремонт при проведении регионально программы капитального ремонта многоквартирных домов. Особенно важным представляется обратить внимание на расчет обоснования минимальной суммы взносов как по региону в целом, так и по каждому муниципалитету в отдельности.

Несмотря на то, что с момента принятия изменений в Жилищный кодекс прошло несколько лет, наблюдается недостаток квалифицированных кадров для региональной системы капитального ремонта многоквартирных домов, особенно на местном уровне.

В последние годы информационные технологии активно входят в нашу жизнь. С началом их активного применения существенно меняется жизнь людей, производственные отношения, а также общая экономическая и социальная структура общества. Необходимо отметить, что все эти изменения касаются не отдельно взятой страны, а всей нашей цивилизации. Естественного, какие-то страны более активно входят в цифровую сферу, какие-то отстают.

В соответствии с индексом сетевой готовности, который призван показывать, насколько качественно та или иная страна использует цифровые технологии в экономике, в 2016 году Россия занимала 41 место по этому показателю, значительно уступая лидерам списка: Сингапуру, Финляндии, США и другим развитым странам [20].

Под цифровой экономикой, в первую очередь, понимается экономическая деятельность, основанная преимущественно на цифровых технологиях, и связанная с электронным бизнесом и электронной коммерцией, а также электронными товарами и услугами. Ее развитие тесно связано с прорывом в научно-технологическом и социальноэкономическом развитии России [21].

С учетом развивающейся цифровизации всех отраслей народного хозяйства представляется целесообразным ускорение внедрения информационных технологий в региональные системы капитального ремонта многоквартирных домов и в сферу ЖКХ в 
целом. Современные цифровые технологии будут способствовать качественному повышению функционирования систем капитального строительства и решению многих из перечисленных выше проблем, таких как создание сбалансированной и обоснованной системы современного мониторинга, расчет необходимых затрат на проведение капитального ремонта с учетом имеющихся финансов на среднесрочную и долгосрочную перспективу, взаимодействие между всеми участниками процесса как по вертикали, так и по горизонтали.

Решение указанных задач поможет организовать субъектам более эффективную систему капитального ремонта, но для этого необходимо продолжать более глубокие научные исследования в данной сфере на основании которых можно будет выработать четкие механизмы преодоления всех проблем отрасли. В конечном счете это приведет к экономическому росту, повышению социально-экономического уровня и создаст дальнейшие предпосылки для активного развития российских регионов в эпоху цифровизации.

\section{Литература:}

1. Минаев Н. Н., Селиверстов А. А., Шадейко Н. Р., Филюшина К. Э., Меркульева Ю. А. Основные проблемы и препятствия для развития региональной системы капитального ремонта многоквартирных домов на современном этапе // Региональная экономика: теория и практика. 2015. № 36. С. 16 - 25.

2. Мищенко В.И., Гудков А.И., Долотова Д.В. О некоторых аспектах законодательного регулирования организации капитального ремонта общего имущества мнооквартирных домов в Российской Федерации // Современная наука: актуальные проблемы теории и практики. Серия: Экономика и право. 2018. № 12. С. $104-107$.

3. Хмелева Г.А., Трифонова Д.Ю. Государственный контроль капитального ремонта многоквартирных домов, проблемы и способы их решения // Вестник науки и образования. 2019. № 10-4 (64). С. $38-40$.

4. Шрейбер К. К., Король Е. А. Теоретические аспекты формирования нормативно-методической базы капитального ремонта общего имущества многоквартирных домов // Вестник МГСУ. 2019 Т. 14. № 11 (134). С. 1473 - 1481/

5. Жилищные условия. Федеральная служба государственной статистики. Режим доступа: https://rosstat.gov.ru/folder/13706 (дата обращения 10.03.2021).

6. Федеральный закон от 21.07.2007 № 185 «О Фонде содействия реформированию» // Российская газета. 27.07.2007. № 162.

7. Капитальный ремонт в многоквартирных домах и тарифы на коммунальные услуги: вопросы и ответы. М. Библиотечка РГ. 2014. 160.

8. Жилищный кодекс Российской Федерации от 29 декабря 2004 г. № 188-Ф3 // Российская газета. 12.01.2005. № 1. 
9. Голубова О. С. Умные города и умные здания: современное состояние и экономическая эффективность // Труды БГТУ. Серия 5: Экономика управления. 2019. № 1 (220). C. $65-72$.

10. Терешкина Т. Р., Семенов А. С. Организационно-логические факторы повышения энергоэффективности в сфере ЖКХ Санкт-Петербурга // ФЭС: Финансы. Экономика. 2020. Т. 17. № 5. С. $20-27$.

11. Бузырев В. В., Дубровская И. В. Реализация жилищной политики в России: перспективы и риски // Проблемы современной экономики. 2014. № 3. С. 238 - 240.

12. Energy Policies and Issues. Ed. Edgar R. Thompson. Nova Science Publishers, Inc., 2011. 196 p.

13. Alicja Siuta-Olcha and Tomasz Cholewa. Energy Saving and Storage in Residential Buildings. Nova Science Publishers, Inc., 2012. 129 p.

14. Energy Efficiency: Methods, Limitations and Challenges. Editors: Emmanuel F. Santos Cavalcanti, Marcos Ribeiro Barbosa. Nova Science Publishers, Inc., 2012. 251 p.

15. Matthew Hall. Materials for Energy Efficiency and Thermal Comfort in Buildings. Woodhead Publishing, 2010. 760 p.

16. Richard B. Howarth, Bo Andersson. Market barriers to energy efficiency // Energy Economics. 1993. Vol. 15. № 4. P. 262-272. doi:10.1016/0140-9883(93)90016-K.

17. Juan D. Gomez, Afamia Elnakat, Martha Wright, Jourdaine Keener. Analysis of the energy index as a benchmarking indicator of potential energy savings in the San Antonio, Texas single-family residential sector// Energy Efficiency. 2015. Vol. 8. № 3. P. 577-593. doi: 10.1007/s12053-014-9310-6.

18. Энергоэффективность в России: скрытый резерв: отчет, подготовленный экспертами Всемирного банка. Международная финансовая корпорация и Центр по эффективному использованию энергии. 2008. 162 с.

19. Блех Е. М., Павленков Ю. В. Альтернативная модель управления капитальным ремонтом многоквартирых домов // Экономика строительства. 2013. № 2. С. $54-62$.

20. Распоряжение правительства РФ от 28 июня 2017 г. № 1632-р «Об утверждении программы «Цифровая экономика Российской Федерации». Режим доступа: http://static.government.ru/media/files/9gFM4FHj4PsB79I5v7yLVuPgu4bvR7M0.pdf (дата обращения 22.08.2020).

21. Шпинев Ю.С. Инвестиции в сельское хозяйство в период цифровизации: анализ ситуации // Пробелы в российском законодательстве. 2020. Т. 13. №6. С. 049-054. DOI: $10.33693 / 2072-3164-2020-13-6-049-054$ 